\title{
Superficial zone cellularity is deficient in mice lacking lubricin: a stereoscopic analysis
}

Naga Padmini Karamchedu', Josef N. Tofte ${ }^{2}$, Kimberly A. Waller ${ }^{1}$, Ling X. Zhang ${ }^{3}$, Tarpit K. Patel ${ }^{1}$ and Gregory D. Jay ${ }^{3,4^{*}}$

\begin{abstract}
Background: Lubricin, a mucinous glycoprotein secreted by synoviocytes and chondrocytes plays an important role in reducing the coefficient of friction in mammalian joints. Elevated cartilage surface friction is thought to cause chondrocyte loss; however, its quantification and methodological approaches have not been reported. We adapted a stereological method and incorporated vital cell staining to assess cellular loss in superficial and upper intermediate zones in lubricin deficient mouse cartilage.
\end{abstract}

Methods: The femoral condyle cartilage of the intact knees from lubricin wild type $\left(\operatorname{Prg} 4^{+/+}\right)$, heterozygote $\left(\operatorname{Prg} 4^{+/}\right)$, and knockout $\left(\mathrm{Prg}^{-1}{ }^{-1}\right.$ ) mice was imaged using fluorescein diacetate (FDA), propidium iodide (PI), and Hoechst staining, and confocal microscopy. Three dimensional reconstructions of confocal images to a depth of $14 \mu \mathrm{m}$ were analyzed using Matlab to determine the volume fraction occupied by chondrocytes in cartilage of both medial and lateral femoral condyles. Living chondrocyte volume fraction was defined as FDA stained chondrocyte volume/total volume of superficial + upper intermediate zone. Living and dead (total) chondrocyte volume fraction was defined as FDA + PI stained chondrocyte volume/total volume of superficial + upper intermediate zone. MicroCT provided an orthogonal measure of cartilage thickness. Immunohistology for activated caspase-3 and TUNEL staining were performed to evaluate the presence of apoptotic chondrocytes in Prg4 mutant mice.

Results: Living chondrocyte volume fraction of the medial femoral condyle was significantly lower in $\mathrm{Prg} 4^{-1}$ mice compared to $\operatorname{Prg}^{+/+}(p=0.002)$ and $\operatorname{Prg}^{+/-}(p=0.002)$ littermates. There was no significant difference in medial condyle chondrocyte volume fraction between $\operatorname{Prg} 4^{+/+}$and $\operatorname{Prg} 4^{+/-}$mice $(p=0.82)$. No significant differences were observed for the chondrocyte volume fraction for the lateral condyle $(p>0.26)$. Cartilage thickness increased in the medial condyle for $\operatorname{Prg} 4^{-/}$mice compared to $\operatorname{Prg}^{+/+}(p=0.02)$ and $\operatorname{Prg}^{+/-}(p=0.03)$ littermates, and the lateral condyle for $\operatorname{Prg}^{-/}$mice compared to $\operatorname{Prg}^{+/+}(p<0.0001)$ and $\operatorname{Prg} 4^{+/}(p<0.0001)$ littermates, indicating that a multi-dimensional increase in cartilage volume did not artifactually lower the chondrocyte volume fraction in the medial condyle. Significantly higher number of caspase-3 positive cells were observed in the superficial and upper intermediate zone cartilage of the medial femoral condyle of $\operatorname{Prg} 4^{-/}$mice compared to $\operatorname{Prg} 4^{+/+}(p=0.01)$ and $\operatorname{Prg}^{+/-}(p=0.04)$ littermates, and the lateral femoral condyle of $\operatorname{Prg}^{-/}$mice compared to $\operatorname{Prg}^{+/+}(p=0.02)$ and $\operatorname{Prg}^{+/-}(p=0.02)$ littermates. There were no significant differences in TUNEL staining among different Prg4 genotypes in both condyles ( $p>0.05$ for all comparisons).

(Continued on next page)

\footnotetext{
* Correspondence: gjay@lifespan.org

${ }^{3}$ Department of Emergency Medicine, Rhode Island Hospital, Providence, RI 02903, USA

${ }^{4}$ Department of Engineering, Brown University, Providence, RI, USA

Full list of author information is available at the end of the article
} 
(Continued from previous page)

Conclusions: Increased Caspase-3 activation is observed in Prg4 deficient mice compared to Prg4 sufficient littermates. Absence of Prg4 induces loss of chondrocytes in the superficial and upper intermediate zone of mouse cartilage that is quantifiable by a novel image processing technique.

Keywords: Articular cartilage, Chondrocyte, Lubricin, Apoptosis, Osteoarthritis, Stereoscopy, Friction

\section{Background}

Lubricin, a mucinous glycoprotein secreted by synoviocytes and chondrocytes [1-3], plays an important role in reducing the coefficient of friction in mammalian joints $[4,5]$. Lubricin knockout $\left(\operatorname{Prg} 4^{-/-}\right)$mice [6] lack lubricin and have increased joint friction during ex vivo loading compared to wild-type mice [4]. The same is true of patients with the camptodactyly-arthropathy-coxa varapericarditis syndrome (CACP). The cartilage of $\mathrm{Prg}^{-/-}$ mice appears normal at birth, but exhibits frictioninduced wear by two weeks of age [4]. In addition to protecting against superficial zone damage [4], lubricin reduces shear-induced cartilage strain [6-8] thereby protecting chondrocytes [9] embedded in cartilage from strain induced apoptosis [8].

Understanding cellular loss in the absence of lubricin may be relevant to other more common rheumatic and orthopedic conditions which display synovitis. The inflammatory component of joint diseases results in a downregulation of lubricin, which is orchestrated by cytokines such as IL1 and TNF $\alpha$ [9-12]. This deficiency is particularly important in understanding post-traumatic osteoarthritis following anterior cruciate ligament (ACL) disruption, for example, where synovial fluid lubricin levels remain diminished for up to a year [13]. Inadequate lubricin has also been observed in rat osteoarthritis (OA) models where lubricin is undetectable at the cartilage surface four weeks following ACL transection [11]. The progression of traumatized cartilage to OA occurs over several years, involves early damage to the cartilage surface, and the loss of chondrocytes, before characteristic joint remodeling [14-17]. Loss of chondrocytes has been attributed to apoptosis, caused by elevated friction in the $\operatorname{Prg} 4^{-/-}$mouse $[18,19]$ and in inflammatory surgical models of OA [20]. A combination of techniques is necessary to confirm apoptosis $[21,22]$. We probed for caspase-3 activation and DNA strand breaks. Linking this cellular loss to a lack of lubricin has motivated the re-examination of mice with mutations in Prg4.

Since Prg $4^{-/-}$mice are congenitally deficient in their lubricating ability, we hypothesized that shear-stress induced chondrocyte apoptosis [8] would reduce the numbers of chondrocytes in the superficial and intermediate zones of articular cartilage. To test this hypothesis, we adapted a stereological method [23] to determine chondrocyte cellularity in three dimensions [24, 25] and incorporated vital cell staining to compare the chondrocyte volume fraction in $\mathrm{Prg}^{+/+}, \mathrm{Prg}^{+/-}$, and Prg $4^{-/-}$mice. By employing confocal microscopy to examine intact articular cartilage surfaces, we were able to avoid the need for histological processing and study larger volumes of articular cartilage. Herein, we describe our confocal imaging technique and report that $\operatorname{Prg}^{-1-}$ mice have significantly fewer articular cartilage chondrocytes than lubricin sufficient mice.

\section{Methods}

All animal research was approved by the Rhode Island Hospital Animal Welfare Committee. The generation of mice with Prg4 knockout alleles has been previously described [26]. In the present study, $\operatorname{Prg} 4^{+/+}, \operatorname{Prg} 4^{+/-}$, and $\mathrm{Prg}^{-/-}$mice were maintained on the C57/Bl6 genetic background.

\section{Sample preparation}

Hind limbs from $\operatorname{Prg} 4^{+/+}, \operatorname{Prg} 4^{+/-}$, and $\operatorname{Prg}^{-/-}$mice of both sexes were harvested following $\mathrm{CO}_{2}$ asphyxiation at ten weeks of age (Additional file 1: Table S1). Left and right knee joints were dissected immediately after euthanasia in order to minimize chondrocyte death. The joint capsule was excised and soft tissue carefully removed to reveal the cartilaginous surface of the lateral and medial femoral condyles. Hind limbs were stained and analyzed by confocal microscopy or microCT (see below), or were fixed in $10 \%$ phosphate buffered formalin (Fisher PROTOCOL ${ }^{\mathrm{ms}}$, Fisher Scientific, Waltham, MA, USA) and embedded in paraffin for activated caspase-3, terminal deoxynucleotidyl transferase dUTP nick end labeling (TUNEL) and 4',6diamidino-2-phenylindole (DAPI) histochemistry.

\section{Staining for confocal microscopy}

Freshly dissected femoral condyles were stained using $1.3 \mu \mathrm{g} / \mathrm{ml}$ fluorescein diacetate (FDA) in PBS (Life Technologies, Cat \# F1303), $0.1 \mu \mathrm{g} / \mathrm{ml}$ propidium iodide (PI) in PBS containing $2.5 \%$ of EDTA (Sigma-Aldrich, Cat \# P4170), and $1.16 \mu \mathrm{g} / \mathrm{ml}$ Hoescht 33342 trihydrochloride trihydrate in PBS (Life Technologies Cat \# H33570) for $5 \mathrm{~min}$ in the dark at room temperature (Fig. 1). Samples then underwent five successive washes with PBS at room temperature and were placed facing downward on glass slides (Fig. 1a). Vectashield mounting medium (Vector Laboratories, Burlingame, CA, USA) was applied to the 

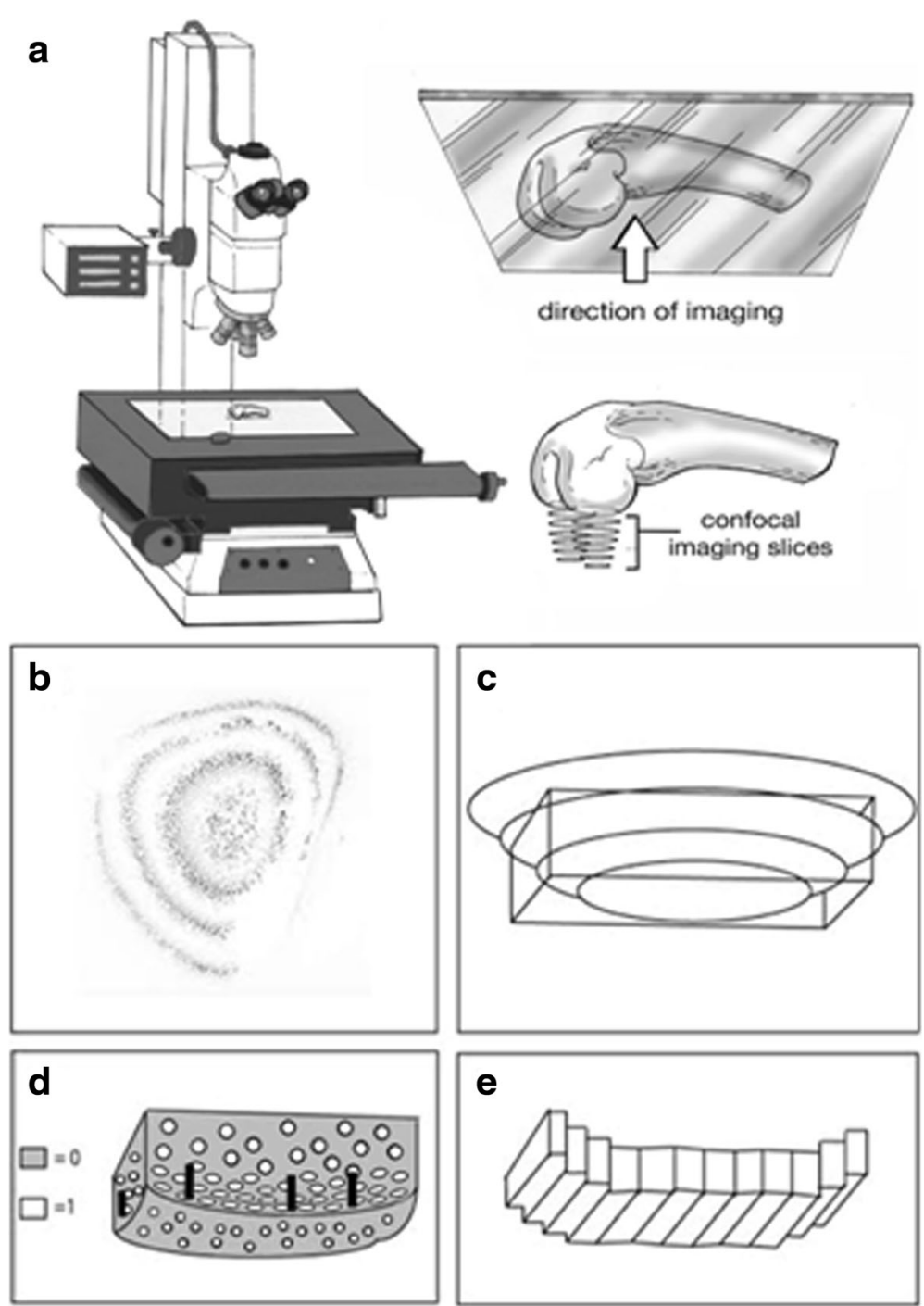

Fig. 1 Schematic describing confocal imaging and processing technique. a Physical positioning of femur during imaging. b Subset of confocal image sections taken of the dome of a medial femoral condyle, looking from the apex downward in the z-direction (image inverted for clarity). c Region of interest (rectangle) selected from the 3D reconstruction of the condyle surface. $\mathbf{d}$ The method used to differentiate space occupied by cells and extracellular matrix. Areas of cellularity were labeled with " 1 " and non-cell areas were labeled with "0". Black bars represent the vertical distance between areas of cellularity within the most superficial and deepest confocal images. Vertical distances were averaged across the width of the section to estimate the thickness of the superficial and upper intermediate zone. e Schematic demonstrating the rectangular prisms created iteratively and used to approximate the volume of the superficial and upper intermediate zone

sample on the glass slide to prevent photo bleaching. FDA is a vital dye that only enters the cytoplasm of living cells. PI enters the cytoplasm of dead cells and binds to DNA. Hoechst stain enters live and dead cells, binds to DNA within the nucleus, and was used as a confirmatory stain for PI.

\section{Image acquisition using confocal microscopy}

Confocal images from 0 to $28 \mu \mathrm{m}$ in depth were acquired with a Nikon C1si confocal microscope (Nikon, Melville, NY, USA) using diode lasers 402, 488, and 561. Serial optical sections were performed with EZ-C1 computer software. Z-series sections were collected every $2 \mu \mathrm{m}$ for a total of 14 images with a 10x PlanApo lens and a scan zoom of 1x. Each wavelength was acquired separately by invoking frame lambda. Imaging time for the stack was less than two minutes. Diode laser power was set to $10 \%$ with a small pinhole. Projections were performed in Elements computer software (Nikon).

\section{Calculating cellularity and volume from the stacked confocal images}

Images $0-14 \mu \mathrm{m}$ in depth were processed using Matlab (Natick, MA, USA) (Fig. 1b) using a customized 

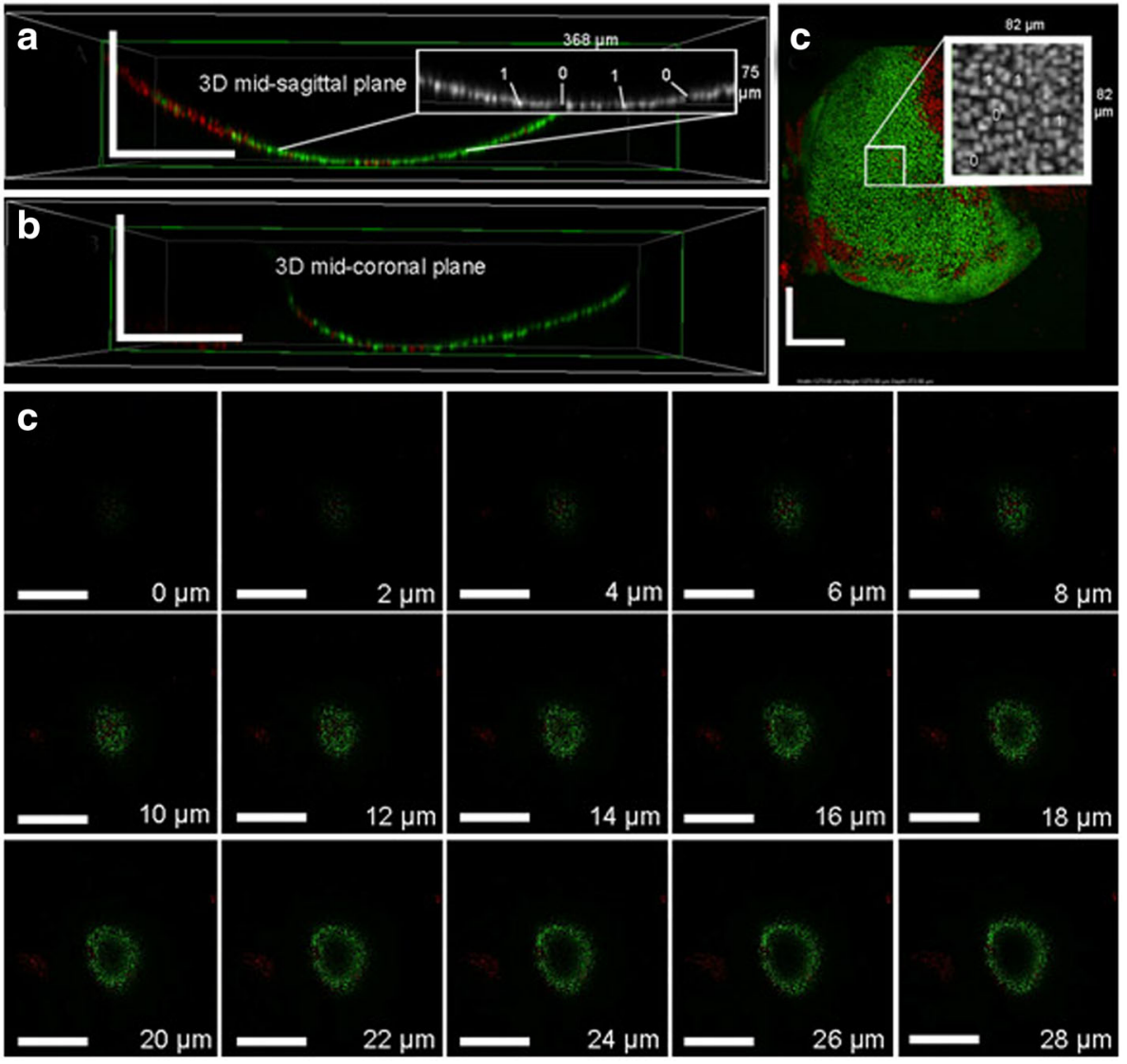

Fig. 2 Representative 3D views showing reconstructed imaging of FDA and PI stained medial femoral condyle. a Mid-sagittal plane of reconstructed condylar images, including the pixel-labeling technique using 1s and 0s (inset). b Mid-coronal plane of reconstructed condylar images. c Reconstructed apical view of condyle with the pixel-labeling technique (inset). Scale bars indicate $250 \mu \mathrm{m}$. $\mathbf{d}$ Confocal z-stack image series showing sample sections from apex of condyle $(0 \mu \mathrm{m})$ down into the medial femoral condyle cartilage thickness $(28 \mu \mathrm{m})$. Estimated thickness of stained cartilage without loss of central cellularity was $14 \mu \mathrm{m}$, which included the superficial and upper intermediate cartilage zones. Scale bars indicate $400 \mu \mathrm{m}$. FDA fluorescein diacetate, P/ propidium iodide

algorithm (Additional file 2: Figure S1). The depth was limited to $14 \mu \mathrm{m}$ to restrict the analysis to the superficial and intermediate zones of weight bearing regions of mouse articular cartilage. A region of interest (ROI) approximating the weight-bearing surface of each condyle was selected from a three-dimensional reconstruction created from the image stacks (Fig. 1b, c). This ROI consisted of approximately the largest rectangular prism contained within the perimeter of the condyle (Fig. 1c). Monochrome images were thresholded to binary images with 1's describing staining and 0's describing absence of staining (Figs. 1d, 2a and c-insets). Images were then morphologically 'skeletonized' to ensure that each connected component had minimal weight and connectivity. This method was performed in order to normalize for differences in brightness, contrast, and staining luminescence between images, and ensure that each stained cell was described by an approximately equal number of pixels. Within this ROI, each vertical column of pixels in the $\mathrm{z}$-direction was sampled to find the vertical distance between the lowest and highest cells, which was averaged in order to provide an approximate measure of thickness across the cartilage surface (Fig. 1e). Thickness was multiplied by the width of the ROI for each horizontal row, thus calculating the volume of the stained cartilage. Data for this calculation is limited by stain penetration and geometry of the curved surface. Images acquired had cells in the first few images and at $14 \mu \mathrm{m}$, a central loss of cellularity was observed when traversing downward through the z-stack, as shown in Fig. 2d. Thus, in order to obtain a reliable measure of thickness only the first eight images of the stack $(14 \mu \mathrm{m}$ of depth) were used. By counting how many sections were traversed, the vertical thickness of the stained layer could be determined, as sections were taken every $2 \mu \mathrm{m}$. The thickness so obtained was used for calculating the superficial + upper intermediate zone volume. This method draws upon one of the stereological tools in microscopy, 
the Cavalieri's principle [27] which establishes that an unbiased measure of volume can be obtained by multiplying the thickness with area. The area here is that occupied and bound by chondrocytes in each slice.

The chondrocyte volume fraction for each condyle was calculated by counting the number of pixels labeled 1 (corresponding to cell staining) on each slice within the previously described ROI. The Holmes effect (i.e., overestimation of area occupied by cells on a slice) as described in the review by Mandarim-de-Lacerda [24], was avoided by using thin optical sections as recommended by Aherne and Dunhill [28], eliminating the need for compensating for average diameter measurements when using tissue sections. This "cell" volume was divided by the volume of the superficial and upper intermediate zone, based on the $14 \mu \mathrm{m}$ depth, in order to find the percent of volume attributable to chondrocyte cellularity for each condyle. The chondrocyte volume fraction is equivalent to the stereological volume fraction described by Howard and Reed [29]. The "reference trap" was thus avoided by establishing reference volume a priori which was calculated the same way across all specimens [23].

\section{Cartilage thickness measurement using microCT imaging to assess the reference volume change}

Mouse femur samples were prepared as described above and incubated in Hexabrix (Guerbet, Bloomington, IN, USA) contrast agent $(15 \%(\mathrm{v} / \mathrm{v})$ in $\mathrm{PBS})$ for $30 \mathrm{~min}$ at room temperature before scanning, which allowed improved contrast between bone and cartilage [30]. The femur was fixated using agarose in an inverted conical tube that was inserted into the $12.3 \mathrm{~mm}$ diameter microCT holder. Samples were imaged in air using $6 \mu \mathrm{m}$ isotropic voxels at $45 \mathrm{kVp}, 177 \mathrm{~mA}$ and $300 \mathrm{~ms}$ integration time (Scanco $\mu \mathrm{CT}$ 40, Bassersdorf, Switzerland). The epiphyseal region of the femur was imaged resulting in a scan time of approximately $45 \mathrm{~min}$. Cartilage was segmented from the microCT scans using Mimics software $\left(\right.$ Mimics $^{\oplus}$, Materialise, Leuven, Belgium). The epiphyseal region of the bone was divided into the medial and lateral compartments using the patellofemoral groove as the midline. A predefined cube was created in Mimics software and was used to outline the most loadbearing region of cartilage for all the samples. A custom Matlab code was used to determine the thickness.

\section{Activated caspase-3 immunohistochemistry}

Coronal mouse knee sections were heated to $60{ }^{\circ} \mathrm{C}$ for $30 \mathrm{~min}$, deparaffinized and hydrated in three changes of $\mathrm{xy}$ lene and serial alcohol. Antigen retrieval was performed using a pepsin solution (Thermo Fisher Scientific, Tewksbury, MA, USA) for $30 \mathrm{~min}$. A rabbit polyclonal antibody against active caspase-3 (cat\#ab13847,
Abcam, Cambridge, MA, USA) at 1:100 dilution with $8 \%$ horse serum in PBS was added to the slides and incubated at $4{ }^{\circ} \mathrm{C}$ overnight. After incubating with a Cy3 goat anti-rabbit IgG (Life Technologies, Catalog\# A10520) at 1:100 dilution for one hour at room temperature in the dark, the sections were washed five times using PBS and coverslipped with vectashield mounting medium with DAPI (Vector Laboratories Inc., Burlingame, CA, USA). Images were captured at 20x with Image-Pro Plus software (Media Cyberkinetics, Bethesda, MD, USA).

\section{TUNEL staining}

A TUNEL assay was performed on coronal mouse knee sections using an ApopTag Plus Peroxidase in situ Apoptosis Kit (Millipore, Billerica, MA, USA). Sections were heated at $60{ }^{\circ} \mathrm{C}$ for $30 \mathrm{~min}$, deparaffinized in three changes of xylene and serial ethanol, then pretreated with proteinase $\mathrm{K}(20 \mu \mathrm{g} / \mathrm{ml})$ for $15 \mathrm{~min}$ at room temperature, quenched with endogenous peroxidase in $3 \%$ hydrogen peroxide for $5 \mathrm{~min}$, and incubated with kit equilibration buffer for $30 \mathrm{~s}$. Excess liquid was tapped off, and the sections were treated with terminal deoxynucleotidyl transferase enzyme at $37{ }^{\circ} \mathrm{C}$ for one hour in a humidified chamber. Sections were then washed three times in PBS, incubated with anti-digoxigenin conjugate for $30 \mathrm{~min}$ at room temperature, and washed in PBS. Peroxidase substrate was applied to sections, which were stained for $8 \mathrm{~min}$., washed in deionized water, and counterstained with $0.5 \%$ methyl green. Sections were washed in deionized water again, dehydrated in xylene three times, and mounted with Permount mounting media. Images were captured at 20x with Image-Pro Plus software.

\section{Two-dimensional cell counting}

Images of thin sections stained with DAPI or probed for activated caspase- 3 were acquired at the same exposure levels in all channels. They were then imported into Adobe Photoshop CS5 software and shadow levels in each channel were adjusted to eliminate background by modifying the histogram using the same values for all the images. Cell counting was performed using ImageJ software. A grid was overlaid on the image, starting at the condyle edge with horizontal lines $14 \mu \mathrm{m}$ apart. Images for TUNEL were acquired in bright field with the same exposure and white balance settings and cell counting was performed as described above.

\section{Statistical analysis}

Percent cellularity, cartilage thickness, and cell number are presented as mean \pm SD. Differences in percent cellularity in a volume, cartilage thickness, and chondrocyte number data across genotypes were analyzed using a 


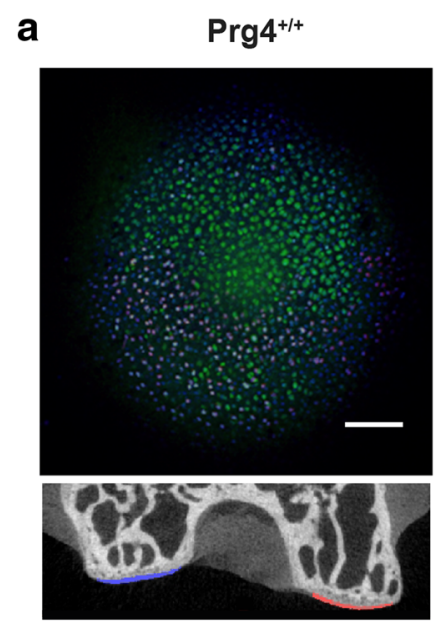

b

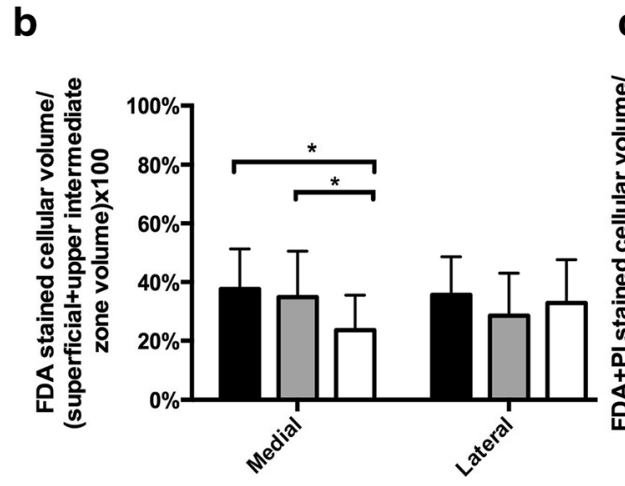

d

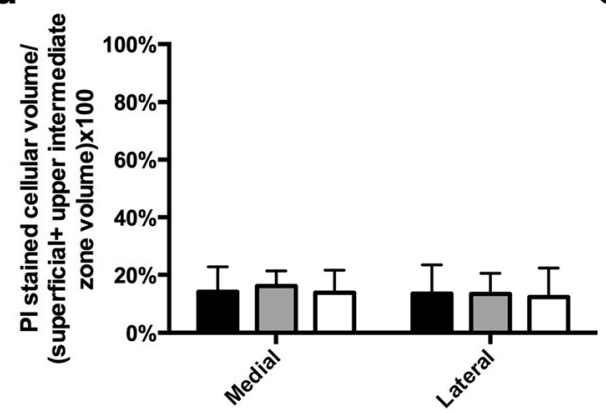

Prg4 ${ }^{+1-}$

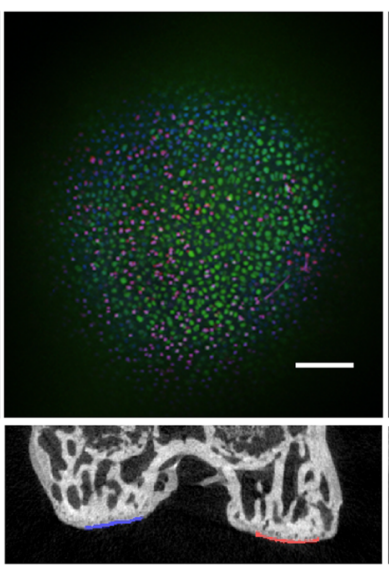

C

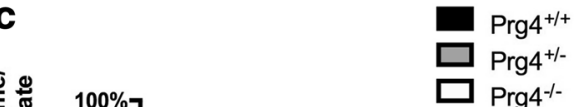

Prg ${ }^{-1-}$

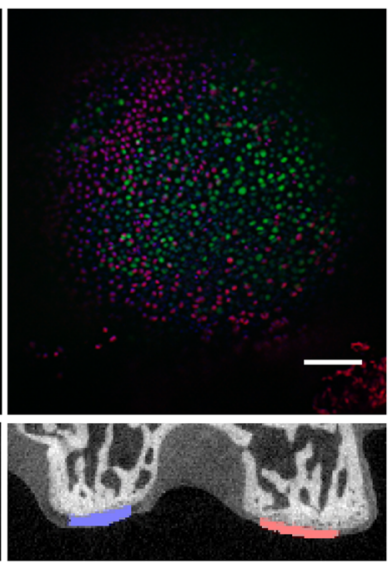

$\mathrm{Prg}^{4-1-}$

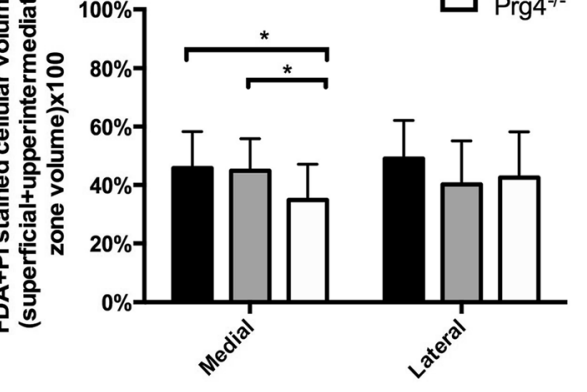

e

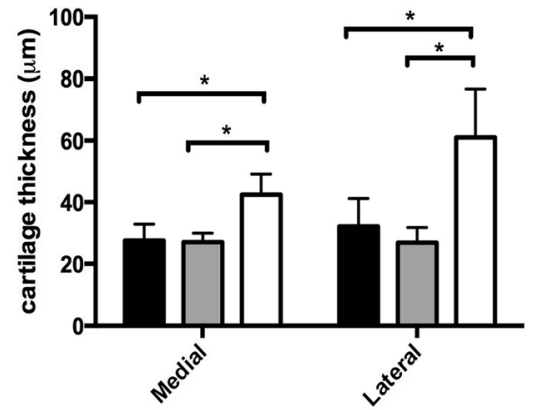

Fig. 3 Chondrocyte volume fraction and cartilage thickness measurements medial and lateral femoral condyle articular cartilage across Prg $4^{+/+}$, Prg $^{+/-}$and Prg $4^{-/-}$mouse knee joints. a Representative median confocal images of FDA (green) + PI (red) + Hoechst (blue) stained medial femoral condyle cartilage presented as a 0 to $14 \mu \mathrm{m}$ depth projection, (first row) used in the calculation of mean percentage of cellular volume in cartilage. Scale bars indicate $10 \mu \mathrm{m}$. Representative microCT coronal sections (second row) illustrating the results of the Mimics cartilage reconstruction. b Superficial and upper intermediate zone living chondrocyte volume fraction (FDA stained cellular volume/superficial + upper intermediate zone volume) measurements for the medial and lateral femoral condyles. Living chondrocyte volume fraction of the medial femoral condyle of Prg $4^{-/-}$mice was significantly less than Prg $4^{+/+}(p=0.002)$ and $\operatorname{Prg}^{+/-}(p=0.002)$ littermates. c Superficial and upper intermediate zone living + dead chondrocyte volume fraction (FDA + PI stained cellular volume/superficial + upper intermediate zone volume) measurements for the medial femoral lateral femoral condyles. Chondrocyte volume fraction of the medial femoral condyle of Prg $4^{/-}$mice was significantly less than Prg $4^{+/+}(p=0.02)$ and Prg $4^{+/-}(p=0.04)$ littermates. d Superficial and upper intermediate zone dead chondrocyte volume fraction (PI stained cellular volume/superficial + upper intermediate zone volume) measurements for medial and lateral femoral condyles. No significant differences were observed between genotypes on medial and lateral condyles. e Mean cartilage thickness determined from microCT, for the medial (blue) and lateral (red) femoral condyle are shown. Cartilage was significantly thicker in Prg $4^{-/-}$medial femoral cartilage compared to Prg $4^{+/+}(p=0.03)$ and Prg ${ }^{+/-}(p=0.02)$ littermates. There was a significant increase in thickness for the lateral femoral condyle in Prg $4^{-/}$compared to Prg $4^{+/+}(p<0.0001)$ and Prg $4^{+/-}(p<0.0001)$ littermates. FDA fluorescein diacetate, PI propidium iodide 
two-way repeated measures ANOVA $(\alpha \leq 0.05)$. Tukey's multiple comparison post hoc tests were used on all data. All statistical analyses were performed using Prism 6 (GraphPad Software Inc., San Diego, CA). The median value images of cellularity and cartilage thickness are depicted.

\section{Results}

Chondrocyte volume fractions determined by FDA stained volume/reference volume for the medial and lateral femoral condyles from wild-type and Prg4 mutant mice

A representative femoral condyle stained with FDA, PI and Hoechst is shown in Fig. 3a. Qualitatively, there appeared to be more PI staining in $\operatorname{Prg}^{-/-}$mice. Staining with FDA across all three genotypes showed stain penetration by depth (Fig. 2) as well as across the face of the condylar cartilage (Fig. 3). The superficial and upper intermediate zone living chondrocyte volume fractions defined as the ratio of FDA-stained (live/ green) cellular volume/total superficial and upper intermediate zone (reference) volume for the medial femoral condyle for lubricin wild type $\left(\operatorname{Prg} 4^{+/+}\right)$, heterozygote $\left(\operatorname{Prg} 4^{+/-}\right)$, and knockout mice $\left(\operatorname{Prg} 4^{-1-}\right)$ were $37.6 \pm$ $13.7 \%(N=20$ knee joints), $31.1 \pm 14.3 \%(N=18)$, and $23.6 \pm 11.9 \%(N=30)$, respectively. The Prg4 $4^{-/-}$mice showed reduced cellularity compared to $\operatorname{Prg}^{+/+}(p=0.002)$ and $\operatorname{Prg} 4^{+/-}(p=0.002)$ littermates (Fig. 3b). There was no significant difference in cellularity between $\operatorname{Prg}^{+/+}$and $\operatorname{Prg}_{4}{ }^{+/-}$mice $(p=0.82)$. In the lateral femoral condyle, living chondrocyte volume fractions for $\operatorname{Prg} 4^{+/+}, \operatorname{Prg} 4^{+/-}$and $\operatorname{Prg} 4^{-/-}$mice were $35.6 \pm 13.1 \%(N=20$ knee joints $)$, $26.9 \pm 12.9 \%(N=18)$, and $30.2 \pm 12.4 \%(N=30)$, respectively. No significant differences were observed across genotypes, $\operatorname{Prg} 4^{+/+}$vs. $\operatorname{Prg} 4^{+/-}(p=0.27), \operatorname{Prg} 4^{+/-}$ vs. $\operatorname{Prg} 4^{-/-}(p=0.55), \quad \operatorname{Prg} 4^{+/+}$vs. $\operatorname{Prg} 4^{-/-} \quad(p=0.78)$ (Fig. 3b).

\section{Chondrocyte volume fraction determined by FDA + PI stained volume/reference volume for the medial and lateral femoral condyles from wild-type and Prg4 mutant mice}

The superficial and upper intermediate zone chondrocyte volume fractions defined as the ratio of FDA + PIstained (living + dead) cellular volume/total superficial and upper intermediate zone (reference) volume for the medial femoral condyle of lubricin wild type $\left(\operatorname{Prg} 4^{+/+}\right)$, heterozygote $\left(\operatorname{Prg}^{+/-}\right)$, and knockout mice $\left(\operatorname{Prg} 4^{-1-}\right)$ were $45.8 \pm 12.6 \%$ ( $N=20$ knee joints $), 44.9 \pm 11.1 \%$ $(N=18)$, and $34.9 \pm 12.2 \%(N=30)$, respectively. The $\operatorname{Prg} 4^{-1-}$ mice showed reduced cellularity compared to $\operatorname{Prg}_{4}^{+/+} \quad(p=0.02)$ and $\operatorname{Prg}_{4}^{+/-} \quad(\mathrm{p}=0.04) \quad$ littermates (Fig. 3c). There was no significant difference in cellularity between $\operatorname{Prg} 4^{+/+}$and $\operatorname{Prg} 4^{+/-}$mice $(\mathrm{p}=0.98)$. For the lateral femoral condyle, total chondrocyte volume fractions for $\operatorname{Prg}_{4}^{+/+}, \operatorname{Prg} 4^{+/-}$and $\operatorname{Prg} 4^{-/-}$mice were $49.1 \pm$ $13.1 \%(N=20$ knee joints), $40.2 \pm 14.9 \%(N=18)$, and $42.5 \pm 15.7 \%(N=30)$, respectively, and were not significantly different, $\operatorname{Prg} 4^{+/+}$vs. $\operatorname{Prg} 4^{+/-}(p=0.11), \operatorname{Prg} 4^{+-}$vs. $\operatorname{Prg}_{4^{-/}}(p=0.84), \operatorname{Prg}_{4}^{+/+}$vs. Prg ${ }^{-/-}(p=0.22)$ (Fig. 3c).

\section{Chondrocyte volume fraction limited to the PI stained volume/reference volume for the medial and lateral femoral condyles from wild-type and Prg4 mutant mice} Mean superficial and upper intermediate zone dead chondrocyte volume fractions measurements defined as the ratio of PI-stained (dead/red) cellular volume/total superficial and upper intermediate zone volume for the medial femoral condyle for lubricin wild type $\left(\operatorname{Prg} 4^{+/+}\right)$, heterozygote $\left(\operatorname{Prg}_{4}^{+-}\right)$, and knockout mice $\left(\operatorname{Prg} 4^{-/-}\right)$were $14.1 \pm 8.7 \%(N=20$ knee joints $), 16.1 \pm 5.3 \%(N=18)$, and $13.8 \pm 7.8 \%(N=30)$, respectively (Fig. $3 \mathrm{~d})$. No significant differences in dead chondrocyte cellularity were observed between groups, $\operatorname{Prg} 4^{+/+}$vs. $\operatorname{Prg} 4^{+/-}(p=0.75)$, $\operatorname{Prg} 4^{+/-}$vs. $\operatorname{Prg} 4^{-/-}(p=0.62), \operatorname{Prg} 4^{+/+}$vs. $\operatorname{Prg} 4^{-/-}(p=1.00)$. For the lateral femoral condyle, dead chondrocyte cellularity for $\operatorname{Prg} 4^{+/+}, \operatorname{Prg} 4^{+/-}$and $\operatorname{Prg} 4^{-/-}$mice was $13.5 \pm$ $10.0 \%, 13.4 \pm 7.1 \%$, and $12.3 \pm 10.0 \%$, respectively. No significant differences were observed across genotypes, $\operatorname{Prg}_{4}^{+/+}$vs. $\operatorname{Prg} 4^{+/-}(p=1.00), \operatorname{Prg} 4^{+/-}$vs. $\operatorname{Prg} 4^{-/-}(p=0.91)$, $\operatorname{Prg}^{+/+}$vs. Prg4 ${ }^{-/-}(p=0.89)$ (Fig. 3d).

Percent of FDA stained chondrocyte volume/FDA + PI stained volume for the medial and lateral femoral condyles from wild-type and Prg4 mutant mice

Mean percent of FDA-positive (live/green) chondrocyte volumes by confocal microscopy divided by FDA + PI stained volume in the superficial and upper intermediate zone (not corrected for superficial and upper intermediate zone volume) for the medial femoral condyle for $\operatorname{Prg} 4^{+/+}, \operatorname{Prg} 4^{+/-}$, and $\operatorname{Prg} 4^{-/-}$mice were $61.9 \pm 26.9 \%$ ( $N=20$ knee joints), $54.6 \pm 18.7 \%(N=18)$, and $63.0 \pm$ $18.9 \%(N=30)$, respectively. There were no significant differences between $\operatorname{Prg} 4^{+/+}$and $\operatorname{Prg} 4^{+/-}(p=0.07)$, and $\mathrm{Prg}^{+/+}$and $\operatorname{Prg}^{-/-}(p=0.98)$ littermates, but differences were observed between $\operatorname{Prg} 4^{+/-}$and $\operatorname{Prg} 4^{-/-}$individuals $(p=0.03)$. In the lateral femoral condyle mean percent of FDA-positive (live/green) staining of chondrocytes by confocal microscopy divided by FDA + PI stained volume in the superficial and upper intermediate zone (not corrected for superficial and upper intermediate zone volume) for $\operatorname{Prg} 4^{+/+}, \operatorname{Prg} 4^{+/-}$, and $\operatorname{Prg} 4^{-1-}$ mice was $72.6 \pm 19.0 \%$ ( $N=20$ knee joints $), 63.9 \pm$ $17.7 \%(N=18)$, and $70.9 \pm 18.7 \%(N=30)$, respectively. There were no significant differences between genotypes in the lateral condyle, $\operatorname{Prg} 4^{+/+}$vs. $\operatorname{Prg} 4^{+/-}(p=0.39), \operatorname{Prg} 4^{+/-}$ vs. $\operatorname{Prg}^{-/-}(p=0.48)$, and $\operatorname{Prg} 4^{+/+}$vs. $\operatorname{Prg} 4^{-/-}(p=0.96)$. 


\section{Cartilage thickness measurements across wild-type and Prg4 mutant mice}

Mean cartilage thicknesses determined from the MIMICS reconstructions for the microCT scans of $\operatorname{Prg} 4^{+/+}, \operatorname{Prg} 4^{+/-}$ and $\operatorname{Prg} 4^{-1-}$ mice ( $N=5$ joints per genotype) for the medial femoral condyle were $27.6 \pm 1.6 \mu \mathrm{m}, 27.0 \pm 1.4 \mu \mathrm{m}$, and 42.4 $\pm 2.6 \mu \mathrm{m}$, and for the lateral femoral condyle were $32.1 \pm$ $1.9 \mu \mathrm{m}, 26.8 \pm 2.1 \mu \mathrm{m}$, and $61.0 \pm 4.3 \mu \mathrm{m}$, respectively. A significant increase in $\mathrm{Prg}^{-/-}$medial femoral condyle cartilage thickness was observed compared to $\operatorname{Prg}^{+/-}(p=0.02)$ and $\operatorname{Prg}^{+/+}(p=0.03)$ mice. No significant differences in medial condyle cartilage thickness were observed between $\operatorname{Prg} 4^{+/+}$ and $\operatorname{Prg}^{+/-}$littermates $(p=1.00)$. A significant increase in $\mathrm{Prg}^{-/}{ }^{-/}$lateral condyle cartilage thickness was also observed compared to $\operatorname{Prg}^{+/+}(p<0.0001)$ and $\operatorname{Prg}^{+/-}(p<0.0001)$ littermates. No significant differences in lateral condyle cartilage thickness were observed between $\operatorname{Prg} 4^{+/+}$and $\operatorname{Prg} 4^{+/-}$ littermates $(p=0.60)$ (Fig. 3e).

\section{Caspase-3 activation in Prg4 null mice}

The mean total number of caspase- 3 positive chondrocytes in superficial and upper intermediate zone (condyle edge to $14 \mu \mathrm{m}$ depth) for $\operatorname{Prg} 4^{+/+}(N=5$ knee joints), Prg4 ${ }^{+/-}(N=4)$, and $\operatorname{Prg}^{-/-}(N=5)$ medial femoral condyle were $3.7 \pm 3.0,8.1 \pm 2.8$ and $28.1 \pm 21.6$, respectively. Similarly, for the lateral femoral condyle, the total number of caspase- 3 positive chondrocytes in superficial and upper intermediate zone for $\operatorname{Prg} 4^{+/+}, \operatorname{Prg} 4^{+/-}$and $\operatorname{Prg}^{-/-}$were $2.1 \pm 1.8,4.2 \pm 2.7$, and $25.4 \pm 15.0$, respectively. There was a significantly higher number of caspase- 3 positive chondrocytes in $\operatorname{Prg} 4^{-/-}$mouse medial femoral condyle cartilage compared to $\operatorname{Prg} 4^{+/+}(p=0.01)$ and $\operatorname{Prg}^{+/-}(p=0.04)$ littermates. Similarly, there was a significantly higher number of caspase-3 positive chondrocytes in $\operatorname{Prg}^{-1-}$ mouse lateral femoral condyle compared to $\operatorname{Prg}^{+/+}(p=0.01)$ and $\operatorname{Prg}^{+/-} \quad(p=0.02)$ littermates (Fig. 4a, c).

\section{TUNEL staining}

The mean total number of TUNEL positive chondrocytes in superficial and upper intermediate zone (condyle edge to $14 \mu \mathrm{m}$ depth $)$ for $\operatorname{Prg} 4^{+/+}(N=5$ knee joints), Prg4 ${ }^{+/-}(N=4)$ and Prg4 ${ }^{-/-}(N=5)$ medial femoral condyle were $3.9 \pm 4.1,9.6 \pm 6.4$, and $5.7 \pm 6.7$, respectively and lateral femoral condyle were $5.9 \pm 4.8,2.0 \pm 1.8$,
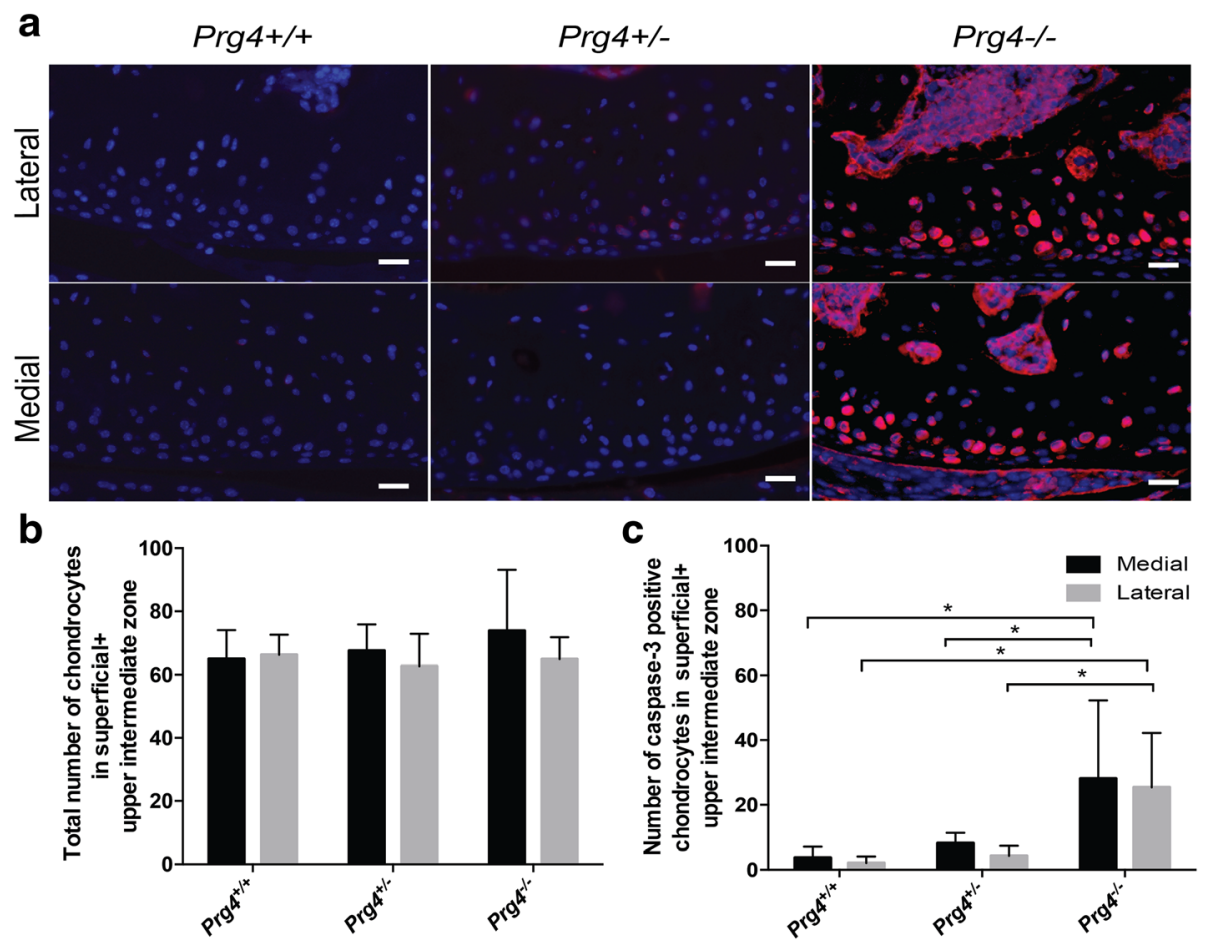

Fig. 4 a Coronal sections of ten-week-old Prg4 mutant mouse medial and lateral femoral condyles stained positive for activated capsase-3. Cells positive for activated caspase-3 are stained pink, while negative nuclei are blue. b No significant differences were observed in the total number of chondrocytes in superficial and upper intermediate zones (14 $\mathrm{mm}$ depth from the edge of the condyle) for $\operatorname{Prg} 4^{+/+}, \operatorname{Prg} 4^{+/-}$and $\operatorname{Prg} 4^{-/ /} \operatorname{littermates}$. c Prg $4^{-1-}$ femoral condyle cartilage had a significantly higher number of cells positive for activated caspase-3 in the superficial and upper intermediate zones (14 $\mu \mathrm{m}$ depth from the edge of the condyle) in the medial femoral condyle compared to $\operatorname{Prg} 4^{+/-}(p=0.04)$ and $\operatorname{Prg} 4^{+/+}(p=0.01) \mathrm{cartilage}$. There was a significantly higher number of caspase positive cells in lateral femoral condyle in $\operatorname{Prg} 4^{-/-}$mice compared to $\operatorname{Prg} 4^{+/-}(p=0.02)$ and $\operatorname{Prg} 4^{+/+}(p=0.01)$ littermates. Scale bars indicate $20 \mu \mathrm{m}$ 
and $5.2 \pm 7.2$. There were no significant differences in the number of TUNEL positive cells in the superficial and upper intermediate zone among different genotypes ( $p>0.05$ for all comparisons).

\section{Traditional thin section cell counting in wild-type and Prg4 mutant mice}

The total number of chondrocytes in the superficial and upper intermediate zones (condyle edge to $14 \mu \mathrm{m}$ depth) for $\operatorname{Prg}^{+/+}\left(N=5\right.$ knee joints), $\operatorname{Prg} 4^{+/-}(N=4)$, and $\operatorname{Prg}^{-1-}(N=5)$ medial femoral condyle were $64.9 \pm 8.2$, $67.5 \pm 7.2$, and $73.8 \pm 17.3$, respectively. For the lateral femoral condyle, the total number of chondrocytes in the superficial and upper intermediate zones (condyle edge to $14 \mu \mathrm{m}$ depth) for $\mathrm{Prg} 4^{+/+}, \mathrm{Prg}_{4}{ }^{+-}$and $\mathrm{Prg} 4^{-/-}$ were $66.3 \pm 5.7,62.7 \pm 9.2$, and $64.9 \pm 6.2$, respectively. No significant differences were observed between groups ( $p>0.05$ for all comparisons) (Fig. 4b).

\section{Discussion}

Though CACP is a rare disorder, it is valuable in understanding the etiology of a number of arthritic conditions, including post-traumatic OA (PTOA) [31-33]. The lubricin knockout mouse recapitulates most of the clinical features of CACP [6]. Evidently, this includes the loss of superficial zone chondrocytes, which is clinically relevant, since patients with $\mathrm{CACP}$ require joint replacement surgery by the third or fourth decade. Lubricin acts as a boundary lubricant, decreasing the friction coefficient in joints at near-zero sliding speeds in order to counteract the shear-induced tissue strain associated with normal articulation [4,5]. The synovial fluid from patients with CACP has no lubricin and is unable to reduce friction in vitro in a mechanical bearing comprised of latex apposed to glass [4]. High friction induces chondrocyte caspase- 3 activation in lubricin null mice. However, whether this translates into cellular loss was unknown $[8,34]$.

Staining of articular cartilage with FDA was previously used to confirm chondrocyte viability across $\operatorname{Prg} 4^{+/+}$, $\mathrm{Prg}^{+/-}$and $\operatorname{Prg} 4^{-/-}$murine knee joints that had been cyclically loaded ex vivo for up to $38 \mathrm{hrs}$ [18]. In that work, and presently, we were unable to find any correlation between Prg4 genotype and the percentage of live cells in the superficial and upper intermediate zone using FDA and standard fluorescence microscopy in two dimensions. However, by measuring the volume of living chondrocytes (green) and combining these data with the volume of dead chondrocytes (red) divided by the cartilage tissue volume for each genotype, our method yielded a reliable metric of superficial and upper intermediate zone cellularity as a chondrocyte volume fraction. A similar stereoscopic metric has been described in a thin section of bovine cartilage imaged by confocal microscopy but that method used a 'dissector' and was semiautomated [35] in that the cells were counted manually by placing a grid in each image of the z-stack. Cell volume fraction has been used in other tissues as well, especially in the brain [36]. The ROI in our study was limited to a depth of $14 \mu \mathrm{m}$ in mouse cartilage from the cartilage surface origin. Figure $2 \mathrm{~d}$ shows a loss of central cellularity in the z-stack at $14 \mu \mathrm{m}$ depth. Thus, digitized tissue volumes imaged up to that depth would be representative of cell and extracellular volume. The fractional value of cell volume fraction we observed, $40 \%$ is greater than $1.65-3.0 \%$ reported for human cartilage [37] and exceeds those of larger quadrupeds [38].

We chose to calculate cellular volume fraction in two ways: 1) using the volume of FDA stained cells in the numerator or 2) the volume of FDA + PI stained cells in the numerator, since there was no prior knowledge regarding the rate of chondrocyte demise in CACP in humans or in mice. As shown in Fig. 3b and c, similar results were observed for both approaches leading to the conclusion that there are fewer chondrocytes in the superficial and intermediate zone in $\operatorname{Prg}^{-1-}$ (lubricin null) cartilage. This result was strengthened upon measuring an increase in cartilage thickness by microCT. Cartilage from $\operatorname{Prg} 4^{-/-}$mice appears thicker than that from $\operatorname{Prg} 4^{+/-}$and $\operatorname{Prg} 4^{+/+}$littermates, which is not due to a thickened lamina splendens formed by serum proteins which biofoul the articular surface in the absence of lubricin $[4,39]$. The lateral and medial femoral condyle cartilage of $\operatorname{Prg}^{-/-}$mice was respectively $47.4 \%$ and $35.1 \%$ thicker compared to $\operatorname{Prg} 4^{+/+}$littermates. $\operatorname{Prg} 4^{+/-}$ mice had a non-significant decrease in thickness, $2 \%$ for medial and $20 \%$ for lateral femoral condyle, compared to $\operatorname{Prg} 4^{+/+}$littermates. However, the reduction in chondrocyte volume fraction was confined to the medial femoral condyle, the major load bearing joint compartment. The multidimensional increase in volume via cartilage swelling does not explain the reduction in chondrocyte volume fraction, since the lateral femoral condyle showed no loss of cell volume fraction. Animal weight is unaffected by these Prg4 mutations [40] and thus would not account for these differences. Cartilage swelling in the medial compartment following injury has been observed previously in a cohort of patients with ACL injury and reconstruction [41] and is not unique to lubricin insufficient mice. The majority of joint loading occurs in the medial articular surfaces of most mammalian joints $[42,43]$. Lubricin deficiency, whether genetic or transient, will result in mechanical strain [7] and apoptosis [8] of subsurface chondrocytes which we observed. Chondrocytes displaying activated caspase- 3 may not ultimately become TUNEL positive. Recently dead cells will stain with PI. However, the chondrocyte volume fraction calculation, limited to the PI stained volume, divided by 
the reference volume, for both femoral condyles failed to detect more dead chondrocytes in cartilage from $\mathrm{Prg} 4^{-/-}$ mice compared to Prg4 sufficient littermates. Based upon our results we posit that a portion of unstained extracellular volume was once occupied by chondrocytes in younger $\operatorname{Prg} 4^{-1}$ mice and would thus also be nondetectable by TUNEL staining. Many chondrocytes in adult $\operatorname{Prg} 4^{-1-}$ mice display caspase- 3 activation and yet these mice do not show a rapid and precipitous joint failure, leading us to also speculate that other mechanisms [44] may exist to inhibit caspase-3. These possibilities may explain our observation that there were no differences in TUNEL positivity across the three Prg4 genotypes.

FDA staining has been established as a robust method for determination of cell viability with consistent viability values measured over time [45]. FDA being a nonpolar compound easily enters the lipid bilayer of viable cell membranes and is hydrolyzed by cytosolic esterases producing fluorescein [46]. Fluorescein, being a polar compound, is not extruded rapidly as this ester becomes accumulated in the cytoplasm, which allows for robust imaging and cell volume determination [46]. Residual esterase activity has been observed in dying pancreatic islet cells producing faint green fluorescence [47]. Frame lambda mode imaging and image processing have compensated for any imperceptible green staining of dying chondrocytes, if present. The combined depth of the superficial, intermediate and deep zones in mouse femoral condyle cartilage is $25 \mu \mathrm{m}$ [48]. The present study is limited by our inability to report actual chondrocyte cell number, but provides a useful and accurate approximation by instead calculating chondrocyte volume fraction in a larger volume occupied by both cells and extracellular matrix - a measure of cell volume density. By contrast, the total number of chondrocytes in the superficial and upper intermediate zone calculated using a traditional method from the condyle edge to a depth of $14 \mu \mathrm{m}$ (Fig. 4b) across the three genotypes showed no differences. Live/(live + dead) cell volume ratio calculation similarly did not indicate cellular loss in the medial femoral condyle of Prg4 null mice.

In animal models of PTOA, damage to the articular cartilage matrix occurs concomitantly with a loss of boundary-lubricating ability of synovial fluid $[9,12]$. The elevated coefficient of friction accompanying this loss occurs concurrently with decreased lubricin synthesis by synovial fibroblasts and superficial zone chondrocytes $[12,49]$. Chondrocyte apoptosis is observed in both humans and animal models following mechanical injury and appears to be closely associated with the progression of cartilage degradation in OA $[14,16,50-52]$. Supplementing synovial fluid with lubricin [53] (tribosupplementation) limits cartilage degeneration in traumatic joint injury as evidenced by less collagen type II degradation in a rodent PTOA model, accompanied by an improvement in joint function in vivo [54-56]. Fewer chondrocytes undergo apoptosis and cartilage degeneration is reduced following tribosupplementation in rodent models of PTOA [56-58]. Decreased lubricin concentrations may correlate with increased production of inflammatory cytokines in guinea pig models of PTOA [59]. The results from this study, and others [8, $54,57]$, indicate that in the absence of lubricin, there is an increase in the demise of superficial and upper intermediate zone chondrocytes.

Limitations of this study include the restriction of mouse age to ten weeks. At that age mouse joints are fully developed and chondrocytes no longer divide which may have restricted our ability to detect greater numbers of cells that stained with PI. Hoechst was used as a confirmatory stain of PI staining of DNA. Fractional cell volume calculations were not performed using Hoechst staining alone since it appeared (Fig. 3a) that FDA competed with Hoechst stain. Future use of this stereoscopic method could be accomplished using Hoechst as the singular vital stain in the event that the proportion of live to dead cells is less relevant than the total cell volume fraction. However, both Hoechst and PI are limited as they will not stain the cytoplasm and thus may not provide a true estimate of cellular volume.

\section{Conclusions}

In the absence of Prg4, there is an increase in the demise of superficial and upper intermediate zone chondrocytes, possibly through increased apoptosis in these zones. Cellular loss can be measured as a loss of stained cell volume compared to the total volume of the cartilage tissue imaged by confocal microscopy. We developed a novel approach to quantify superficial and upper intermediate zone cellularity in the intact bearing surface of mouse femoral condyles that does not require fixation. Imaging cartilage with a larger radius of curvature from other species would result in imaging of chondrocytes deeper in the $\mathrm{z}$-stack before the central loss of cellularity as observed in Fig. 2d. The cartilage structure is not damaged during imaging, and could theoretically be mechanically tested either before or after imaging.

\section{Additional files}

Additional file 1: Table S1. Prg4 wild-type and mutant mice utilization for chondrocyte volume fraction determination of the medial and lateral femoral condyle by genotype, sex and knee laterality. (PDF $110 \mathrm{~kb}$ )

Additional file 2: Figure S1. Matlab script for chondrocyte volume fraction calculation. (PDF $110 \mathrm{~kb}$ ) 


\section{Abbreviations}

CACP: Camptodactyly-arthropathy-coxa vara-pericarditis; DAPI: 4,6-diamidino2-phenylindole; FDA: Fluorescein diacetate; OA: Osteoarthritis; PI: Propidium iodide; PRG4: Lubricin; PTOA: Post-traumatic osteoarthritis; TUNEL: Terminal deoxynucleotidyl transferase nick end labeling.

\section{Competing interests}

The authors, except for Dr. Gregory D Jay, have no competing financial or non-financial interests. GDJ has authored and was granted a United States patent "Tribonectin polypetides and uses thereof," no. 6743774 for the therapeutic use of lubricin in joints. Dr. Jay receives support from a Phase II STTR for clinical translation efforts related to his patent. The present paper neither materially nor financially affects Dr. Jay's patent relating to rhPRG4. This does not alter the authors' adherence to policies on sharing data and materials.

\section{Authors' contributions}

NPK performed dissections, collected and analyzed the confocal microscopy and microCT data, performed statistical analyses and analyzed caspase-3 data and drafted the original and revised manuscript. JNT wrote the Matlab code for chondrocyte volume fraction determination. LXZ performed DAPI and caspase-3 staining. TKP designed the microCT protocol, helped analyze and interpret microCT data and drafted responses for microCT related questions. KAW performed the TUNEL staining and analyzed the TUNEL data for the original and revised manuscript. GDJ and JNT participated in the design of the study and the drafting of the original and revised manuscript. GDJ helped obtain funding for the study, data analysis and interpretation. All authors read and approved the final manuscript.

\section{Acknowledgements}

The authors thank Virginia Hovanesian for her assistance with confocal microscopy and acknowledge support from US National Institutes of Health Grants RO1-AR050180, P20-RR024484, CDMRP PR1 10746 and R42 AR057276.

\section{Author details}

'Department of Orthopedics, Rhode Island Hospital; Warren Alpert Medical School of Brown University, Providence, RI, USA. '2 Department of Orthopedics and Rehabilitation, University of lowa Hospitals and Clinics, lowa City, IA, USA. ${ }^{3}$ Department of Emergency Medicine, Rhode Island Hospital, Providence, RI 02903, USA. Department of Engineering, Brown University, Providence, $\mathrm{RI}$, USA.

Received: 8 June 2015 Accepted: 4 March 2016 Published online: 14 March 2016

\section{References}

1. Jay GD. Characterization of a bovine synovial fluid lubricating factor. I. Chemical, surface activity and lubricating properties. Connect Tissue Res. 1992;28:71-88

2. Jay $G D$, Britt $D E$, Cha CJ. Lubricin is a product of megakaryocyte stimulating factor gene expression by human synovial fibroblasts. J Rheumatol. 2000;27(3):594-600.

3. Flannery CR, Hughes CE, Schumacher BL, Tudor D, Aydelotte MB, Kuettner $\mathrm{KE}$, Caterson B. Articular cartilage superficial zone protein (SZP) is homologous to megakaryocyte stimulating factor precursor and is a multifunctional proteoglycan with potential growth-promoting, cytoprotective, and lubricating properties in cartilage metabolism. Biochem Biophys Res Commun. 1999;254(3):535-41.

4. Jay GD, Torres JR, Rhee DK, Helminen HJ, Hytinnen MM, Cha CJ, Elsaid K, Kim KS, Cui Y, Warman ML. Association between friction and wear in diarthrodial joints lacking lubricin. Arthritis Rheum. 2007;56(11):3662-9.

5. Gleghorn JP, Jones AR, Flannery CR, Bonassar LJ. Boundary mode lubrication of articular cartilage by recombinant human lubricin. J Orthop Res. 2009;27(6):771-7.

6. Rhee DK, Marcelino J, Baker M, Gong Y, Smits P, Lefebvre V, Jay GD, Stewart M, Wang H, Warman ML et al. The secreted glycoprotein lubricin protects cartilage surfaces and inhibits synovial cell overgrowth. J Clin Invest. 2005;115(3):622-31.

7. Wong BL, Bae WC, Chun J, Gratz KR, Lotz M, Sah RL. Biomechanics of cartilage articulation: effects of lubrication and degeneration on shear deformation. Arthritis Rheum. 2008;58(7):2065-74.
8. Waller KA, Zhang LX, Elsaid KA, Fleming BC, Warman ML, Jay GD. Role of lubricin and boundary lubrication in the prevention of chondrocyte apoptosis. Proc Natl Acad Sci U S A. 2013;110(15):5852-7.

9. Elsaid KA, Jay GD, Warman ML, Rhee DK, Chichester CO. Association of articular cartilage degradation and loss of boundary-lubricating ability of synovial fluid following injury and inflammatory arthritis. Arthritis Rheum. 2005;52(6):1746-55.

10. Elsaid KA, Jay GD, Chichester CO. Reduced expression and proteolytic susceptibility of lubricin/superficial zone protein may explain early elevation in the coefficient of friction in the joints of rats with antigen-induced arthritis. Arthritis Rheum. 2007;56(1):108-16.

11. Elsaid KA, Machan JT, Waller K, Fleming BC, Jay GD. The impact of anterior cruciate ligament injury on lubricin metabolism and the effect of inhibiting tumor necrosis factor alpha on chondroprotection in an animal model. Arthritis Rheum. 2009;60(10):2997-3006.

12. Jones AR, Chen S, Chai DH, Stevens AL, Gleghorn JP, Bonassar LJ, Grodzinsky AJ, Flannery CR. Modulation of lubricin biosynthesis and tissue surface properties following cartilage mechanical injury. Arthritis Rheum. 2009:60(1):133-42

13. Elsaid KA, Fleming BC, Oksendahl HL, Machan JT, Fadale PD, Hulstyn MJ, Shalvoy RM, Jay GD. Decreased lubricin concentrations and markers of joint inflammation in synovial fluids from patients with anterior cruciate ligament injury. Arthritis Rheum. 2008;58(6):1707-15.

14. Musumeci G, Loreto C, Carnazza ML, Martinez G. Characterization of apoptosis in articular cartilage derived from the knee joints of patients with osteoarthritis. Knee Surg Sports Traumatol Arthrosc. 2011;19(2):307-13.

15. Thomas CM, Fuller CJ, Whittles CE, Sharif M. Chondrocyte death by apoptosis is associated with the initiation and severity of articular cartilage degradation. Int J Rheum Dis. 2011;14(2):191-8.

16. Almonte-Becerril M, Navarro-Garcia F, Gonzalez-Robles A, Vega-Lopez MA, Lavalle C, Kouri JB. Cell death of chondrocytes is a combination between apoptosis and autophagy during the pathogenesis of Osteoarthritis within an experimental model. Apoptosis. 2010;15(5):631-8.

17. Aigner T, McKenna L. Molecular pathology and pathobiology of osteoarthritic cartilage. Cell Mol Life Sci. 2002;59(1):5-18.

18. Drewniak El, Jay GD, Fleming BC, Zhang L, Warman ML, Crisco JJ. Cyclic loading increases friction and changes cartilage surface integrity in lubricinmutant mouse knees. Arthritis Rheum. 2012;64(2):465-73.

19. Hill A, Waller KA, Cui Y, Allen JM, Smits P, Zhang LX, Ayturk UM, Hann S, Lessard SG, Zurakowski D et al. Lubricin restoration in a mouse model of congenital deficiency. Arthritis Rheumatol. 2015;67(11):3070-81.

20. Elsaid KA, Zhang L, Shaman Z, Patel C, Schmidt TA, Jay GD. The impact of early intra-articular administration of interleukin-1 receptor antagonist on lubricin metabolism and cartilage degeneration in an anterior cruciate ligament transection model. Osteoarthritis Cartilage. 2015;23(1):114-21.

21. Grogan SP, Aklin B, Frenz M, Brunner T, Schaffner T, Mainil-Varlet P. In vitro model for the study of necrosis and apoptosis in native cartilage. J Pathol. 2002;198(1):5-13.

22. Dang AC, Kim HT. Chondrocyte apoptosis after stimulated intraarticular fracture: a comparison of histologic detection methods. Clin Orthop Relat Res. 2009;467(7):1877-84.

23. Gundersen HJ, Bendtsen TF, Korbo L, Marcussen N, Moller A, Nielsen K, Nyengaard JR, Pakkenberg B, Sorensen FB, Vesterby A et al. Some new, simple and efficient stereological methods and their use in pathological research and diagnosis. APMIS. 1988;96(5):379-94.

24. Mandarim-de-Lacerda CA. Stereological tools in biomedical research. An Acad Bras Cienc. 2003;75(4):469-86.

25. Guilak F. Volume and surface area measurement of viable chondrocytes in situ using geometric modelling of serial confocal sections. J Microsc. 1994; 173(Pt 3):245-56

26. Ruan MZ, Erez A, Guse K, Dawson B, Bertin T, Chen Y, Jiang MM, Yustein J, Gannon F, Lee BH. Proteoglycan 4 expression protects against the development of osteoarthritis. Sci Transl Med. 2013;5(176):176ra134.

27. Mouton PR, Gokhale AM, Ward NL, West MJ. Stereological length estimation using spherical probes. J Microsc. 2002;206(Pt 1):54-64.

28. Aherne WA, Dunhill MS. Morphometry. London: Edward Arnold; 1982.

29. Howard CV, Reed MG. Unbiased Stereology. 2nd ed. New York: Garland Science/BIOS Scientific Publishers; 2005.

30. Kotwal N, Li J, Sandy J, Plaas A, Sumner DR. Initial application of EPIC-muCT to assess mouse articular cartilage morphology and composition: effects of aging and treadmill running. Osteoarthritis Cartilage. 2012;20(8):887-95. 
31. Brown TD, Johnston RC, Saltzman CL, Marsh JL, Buckwalter JA. Posttraumatic osteoarthritis: a first estimate of incidence, prevalence, and burden of disease. J Orthop Trauma. 2006;20(10):739-44.

32. Anderson DD, Chubinskaya S, Guilak F, Martin JA, Oegema TR, Olson SA, Buckwalter JA. Post-traumatic osteoarthritis: improved understanding and opportunities for early intervention. J Orthop Res. 2011;29(6):802-9.

33. Coles JM, Zhang L, Blum JJ, Warman ML, Jay GD, Guilak F, Zauscher S. Loss of cartilage structure, stiffness, and frictional properties in mice lacking PRG4. Arthritis Rheum. 2010;62(6):1666-74

34. Marcelino J, Carpten JD, Suwairi WM, Gutierrez OM, Schwartz S, Robbins C, Sood R, Makalowska I, Baxevanis A, Johnstone B et al. CACP, encoding a secreted proteoglycan, is mutated in camptodactyly-arthropathy-coxa vara-pericarditis syndrome. Nat Genet. 1999;23(3):319-22.

35. Wong M, Wuethrich $P$, Eggli $P$, Hunziker E. Zone-specific cell biosynthetic activity in mature bovine articular cartilage: a new method using confocal microscopic stereology and quantitative autoradiography. J Orthop Res. 1996;14(3):424-32.

36. Moyer CE, Delevich KM, Fish KN, Asafu-Adjei JK, Sampson AR, DorphPetersen KA, Lewis DA, Sweet RA. Intracortical excitatory and thalamocortical boutons are intact in primary auditory cortex in schizophrenia. Schizophr Res. 2013;149(1-3):127-34.

37. Hunziker EB, Quinn TM, Hauselmann HJ. Quantitative structural organization of normal adult human articular cartilage. Osteoarthritis Cartilage. 2002;10(7):564-72.

38. Stockwell RA. Chondrocytes. J Clin Pathol Suppl (R Coll Pathol). 1978;12:7-13

39. Rhee DK, Marcelino J, Al-Mayouf S, Schelling DK, Bartels CF, Cui Y, Laxer R, Goldbach-Mansky R, Warman ML. Consequences of disease-causing mutations on lubricin protein synthesis, secretion, and post-translational processing. J Biol Chem. 2005;280(35):31325-32.

40. Teeple E, Aslani K, Shalvoy MR, Medrano JE, Zhang L, Machan JT, Fleming $B C$, Jay GD. Lubricin deficiency in the murine lumbar intervertebral disc results in elevated torsional apparent modulus. J Biomech 2015;48(10):2210-3.

41. Jones MH, Spindler KP, Fleming BC, Duryea J, Obuchowski NA, Scaramuzza EA, Oksendahl HL, Winalski CS, Duong CL, Huston LJ et al. Meniscus treatment and age associated with narrower radiographic joint space width 2-3 years after ACL reconstruction: data from the MOON onsite cohort. Osteoarthritis Cartilage. 2015;23(4):581-8.

42. Wei $L$, de Bri E, Lundberg A, Svensson O. Mechanical load and primary guinea pig osteoarthrosis. Acta Orthop Scand. 1998;69(4):351-7.

43. Wang SX, Arsenault L, Hunziker EB. Stereologic analysis of tibial-plateau cartilage and femoral cancellous bone in guinea pigs with spontaneous osteoarthritis. Clin Orthop Relat Res. 2011;469(10):2796-805.

44. Riedl SJ, Renatus M, Schwarzenbacher R, Zhou Q, Sun C, Fesik SW, Liddington RC, Salvesen GS. Structural basis for the inhibition of caspase-3 by XIAP. Cell. 2001;104(5):791-800.

45. Jones $\mathrm{KH}$, Senft JA. An improved method to determine cell viability by simultaneous staining with fluorescein diacetate-propidium iodide. J Histochem Cytochem. 1985;33(1):77-9.

46. Rotman B, Papermaster BW. Membrane properties of living mammalian cells as studied by enzymatic hydrolysis of fluorogenic esters. Proc Natl Acad Sci U S A. 1966;55(1):134-41.

47. Boyd V, Cholewa OM, Papas KK. Limitations in the use of fluorescein diacetate/propidium iodide (FDA/PI) and cell permeable nucleic acid stains for viability measurements of isolated islets of Langerhans. Curr Trends Biotechnol Pharm. 2008;2(2):66-84.

48. Hughes LC, Archer CW, ap Gwynn I. The ultrastructure of mouse articular cartilage: collagen orientation and implications for tissue functionality. A polarised light and scanning electron microscope study and review. Eur Cell Mater. 2005;9:68-84

49. Young AA, McLennan S, Smith MM, Smith SM, Cake MA, Read RA, Melrose J, Sonnabend DH, Flannery CR, Little CB. Proteoglycan 4 downregulation in a sheep meniscectomy model of early osteoarthritis. Arthritis Res Ther. 2006;8(2):R41.

50. Waller KA, Zhang LX, Fleming BC, Jay GD. Preventing friction-induced chondrocyte apoptosis: comparison of human synovial fluid and hylan G-F 20. J Rheumatol. 2012;39(7):1473-80.
51. Hashimoto S, Nishiyama T, Hayashi S, Fujishiro T, Takebe K, Kanzaki N, Kuroda R, Kurosaka M. Role of p53 in human chondrocyte apoptosis in response to shear strain. Arthritis Rheum. 2009;60(8):2340-9.

52. D'Lima DD, Hashimoto S, Chen PC, Colwell CW, Lotz MK. Impact of mechanical trauma on matrix and cells. Clin Orthop Rel Res. 2001;3915:590-9.

53. Ludwig TE, McAllister JR, Lun V, Wiley JP, Schmidt TA. Diminished cartilagelubricating ability of human osteoarthritic synovial fluid deficient in proteoglycan 4: Restoration through proteoglycan 4 supplementation. Arthritis Rheum. 2012;64(12):3963-71.

54. Jay GD, Fleming BC, Watkins BA, McHugh KA, Anderson SC, Zhang LX, Teeple E, Waller KA, Elsaid KA. Prevention of cartilage degeneration and restoration of chondroprotection by lubricin tribosupplementation in the rat following anterior cruciate ligament transection. Arthritis Rheum. 2010;62(8):2382-91.

55. Teeple E, Elsaid KA, Jay GD, Zhang L, Badger GJ, Akelman M, liss TF, Fleming BC. Effects of supplemental intra-articular lubricin and hyaluronic acid on the progression of posttraumatic arthritis in the anterior cruciate ligamentdeficient rat knee. Am J Sports Med. 2011;39(1):164-72.

56. Jay GD, Elsaid KA, Kelly KA, Anderson SC, Zhang L, Teeple E, Waller K, Fleming BC. Prevention of cartilage degeneration and gait asymmetry by lubricin tribosupplementation in the rat following anterior cruciate ligament transection. Arthritis Rheum. 2012;64(4):1162-71.

57. Elsaid KA, Zhang L, Waller K, Tofte J, Teeple E, Fleming BC, Jay GD. The impact of forced joint exercise on lubricin biosynthesis from articular cartilage following ACL transection and intra-articular lubricin's effect in exercised joints following ACL transection. Osteoarthritis Cartilage. 2012;20(8):940-8.

58. Flannery CR, Zollner R, Corcoran C, Jones AR, Root A, Rivera-Bermudez MA, Blanchet T, Gleghorn JP, Bonassar LJ, Bendele AM et al. Prevention of cartilage degeneration in a rat model of osteoarthritis by intraarticular treatment with recombinant lubricin. Arthritis Rheum. 2009;60(3):840-7.

59. Teeple E, Elsaid KA, Fleming BC, Jay GD, Aslani K, Crisco JJ, Mechrefe AP. Coefficients of friction, lubricin, and cartilage damage in the anterior cruciate ligament-deficient guinea pig knee. J Orthop Res. 2008;26(2):231-7.

\section{Submit your next manuscript to BioMed Central and we will help you at every step:}

- We accept pre-submission inquiries

- Our selector tool helps you to find the most relevant journal

- We provide round the clock customer support

- Convenient online submission

- Thorough peer review

- Inclusion in PubMed and all major indexing services

- Maximum visibility for your research

Submit your manuscript at www.biomedcentral.com/submit 